\title{
Foreign Direct Investment, Economic Growth, and Environmental Concern: Evidence from Nigeria
}

\author{
*Jonathan D. Danladi ${ }^{1}$, Kehinde John Akomolafe ${ }^{2}$ \\ ${ }^{1}$ University of Ibadan, Ibadan Nigeria \\ ${ }^{2}$ Afe Babalola University, Ado-Ekiti Nigeria \\ *jonathandanladi@yahoo.com
}

\begin{abstract}
One of the reasons pointed out, as the major cause of low investment in Nigeria is low saving. To bridge the saving-investment gap, there have been calls for inflow of foreign direct investment into the country. However, there are arguments about the impacts of FDI on the host country. Principal among the various arguments is its effect on environmental degradation. This paper sets out to examine the validity of this perception using Granger causality test. It examines the direction of causality between FDI and economic growth, Economic growth and Pollution, FDI and Pollution. The results revealed that there is no causality between the growth rate of GDP and FDI, growth rate of GDP and $\mathrm{Co}_{2}$. The only causality found is a unidirectional causality between the growths of FDI grows and the growth rate of pollution. The direction is from growth rate of FDI to the growth rate of pollution. This paper concludes that government should make policy that will ensure that multinational companies use equipment that is environmentally friendly.
\end{abstract}

Keywords: Foreign Direct Investment, Economic Growth, Pollution, $\mathrm{CO}_{2}$, Co-integration, Granger Causality, Multinational Corporation

\section{Introduction}

Motivation: One of the reasons that have been pointed out as the major cause of low investment, and consequently, low development in Nigeria is low saving. This has been said to be a result of the country's low per capital income, and poor financial sector development. To bridge the saving-investment gap in the country, there have been several calls for inflow of foreign direct investment into the country. According to Adegbite and Ayadi (2010), FDI helps to fill the domestic gap between revenue generated and expenditure in developing countries .This is so because many developing countries' governments are not able to generate enough revenue to meet their expenditure needs. Aliyu (2005) argued that foreign investment is useful to bridge the domestic savings gap, provide foreign exchange, and improve balance of payment in Nigeria .It also helps in increasing managerial abilities in the country, FDI can also help in transfer of technology and foster technical expertise linkages with local firms (Aitken\& Harrison, 1999). In addition, FDI helps in bridging the capital shortage gap and complement domestic investment especially when it flows to a high risk areas of new firms where domestic resource is limited (Noorzoy, 1979). Jenkin and Thomas (2002) asserted that FDI is expected to contribute to economic growth not only by providing foreign capital but also by crowding in additional domestic investment. Based on these arguments, developing countries, especially, Nigeria, has offered incentives to encourage inflow of foreign direct investment into the country. This include implementation of IMF monitored liberalization of its economy, attraction of foreign investors in the manufacturing sector, incentives for ownership of equity in all industries, tax relief for investors and concessions for local raw material development in line with the country's economic reforms, etc. As a result of this, Nigeria's share of FDI inflow to Africa averaged around 10\%, from $24.19 \%$ in 1990 and up to $11.65 \%$ in 2002. Nigerian is shown as the continent's second top FDI recipient after Angola in 2001 and 2002.

In addition, Nigeria attracted $70 \%$ of FDI inflow to West Africa and 11\% of Africa's total. Out of this, the oil sector received $90 \%$ of the FDI inflow (UNCTAD, 2003). Despite the increased inflow of FDI to the country, Nigeria's economic growth is still sluggish. This makes it imperative for one to ask the pertinent question as to whether FDI inflow can contribute to the growth of the economy or not. This is one of the major concerns of this paper. Another concern of this paper is the effect of FDI inflow on the environment. This is based on what is known as the pollution havens hypothesis. Environmental quality, FDI, and economic growth are 
often portrayed as being in conflict with one another. An increase in FDI will increase economic activities, and inevitably leads to inclement environment. However, reducing environmental pollution is seen as limiting growth. This work sets out to examine the validity of this perception; to investigate the causal relationships between CO2 emission, FDI and economic growth in Nigeria between 1977 and 2010. Using Co-integration and Granger causality test, it examines the direction of causality between FDI and economic growth, economic growth and pollution, and FDI and pollution. This study is unique in the sense that no study has looked at the relationship between the three variables in Nigeria context. The rest of the paper is organized as follows; Section II gives a brief background to the study and highlights of some theoretical issues. Section III presents previous works that examined the relationship between FDI, Growth and the environment. Section IV describes the data sources and methodology .Section V presents the discussion of result and policy implication. Section VI concludes this paper with recommendation for policy purposes.

Background and Theoretical Issues: Figure 1 below show the trends of the GDP of the country. It is observed that the GDP has maintained a steady rise since the 1970 s at an average growth rate of $24.2 \%$. The growth of the GDP increased tremendously after 1999. This may be explained by the country's enthronement of democracy the witnessed a turnaround and improvement in most economic transactions and variables in the country.

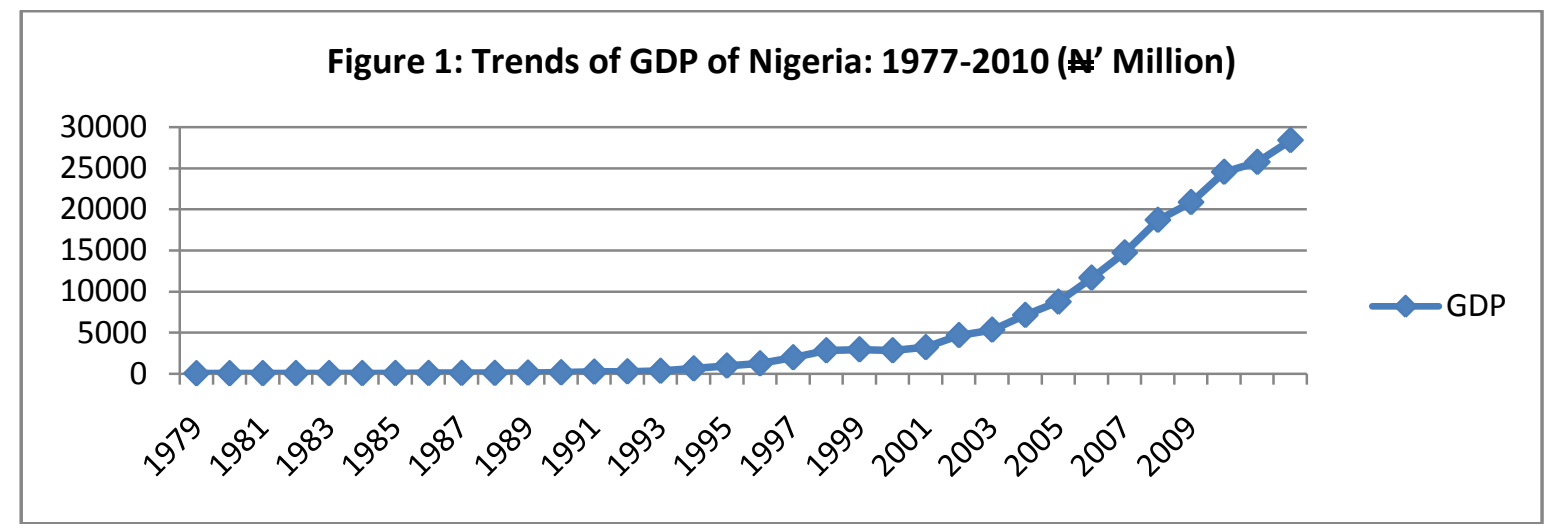

Source: Authors' Computation, Various Issues

Figure 2 below shows the trend of FDI of the country within the period 1977-2010. The trend reveals some volatilities especially as compared to the GDP trend. The average growth rate of FDI in the country since 1977 has been has been around 31\%. FDI into the country witnessed a jump between 1989 and 1991. This was within the period of the return of the country to democracy: the Shagari era before the military took over power again. Nigeria's final enthronement of democracy in 1999 indisputably flipped the country's FDI upwards in no small way. This is obvious having returned to the community of globally democratic economies.

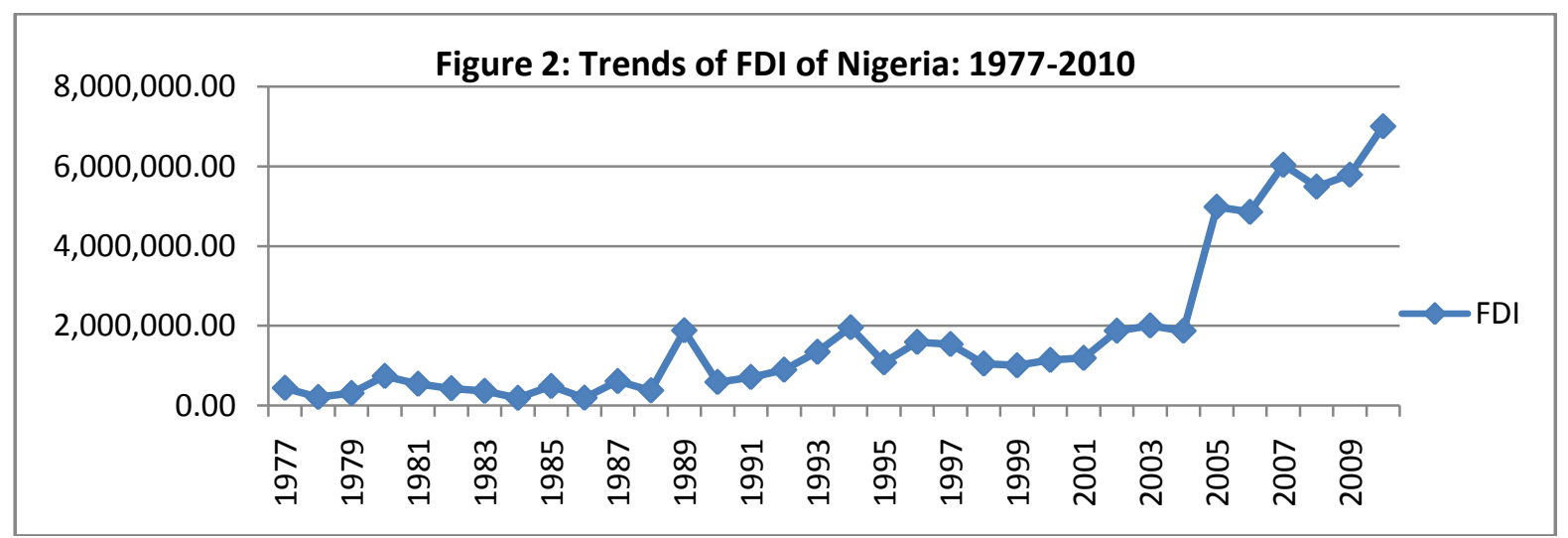

Source: Authors' Computation, Various Issues 
The prevailing political stability and friendly investment climate has indubitably attracted sufficient FDI and a positive net capital flow (capital inflow outstripping capital flight). Over the period 1977-2010, the average growth rate of carbon emissions in the country revolves around 4.3\%. As shown in figure 3 below, the rate witnessed a significant rise in 1999. It rose to 79.1kt between 1999 and 2000, representing about 76.8\% increase over 1999 figure of 44.8kt. Since then, pollution has been on the increase. The fact behind these figures cannot be farfetched as the increase as explained earlier corresponds to the period of the enthronement of democracy in the country-leading to the attraction of FDI (and relative industrialization) and its concomitant pollution.

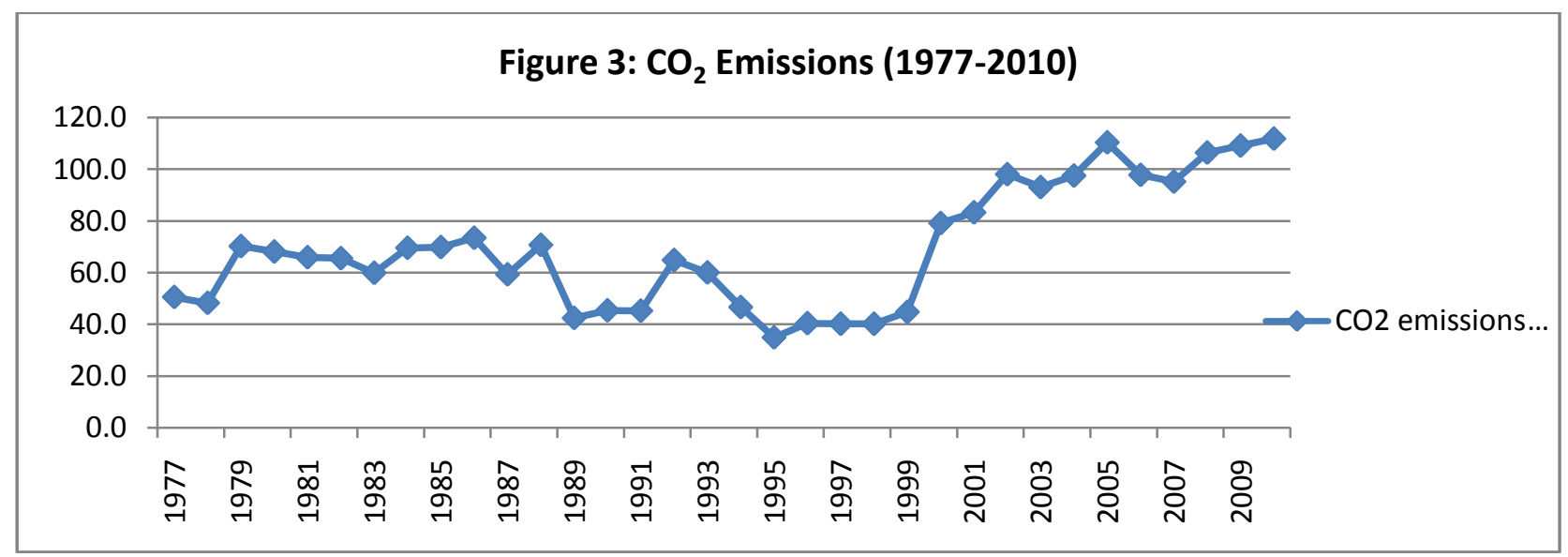

Source: Authors' Computation, Various Issues

The pollution haven hypothesis states that with weak environmental regulations, polluting industries will relocate from where there are stringent regulations to countries with little or no regulations. According to Levinson (2003), environmental regulations raise the cost of production, and reduce the comparative advantage of the polluting industries. The "pollution havens" hypothesis anticipates the voluntary inflows of foreign companies to countries where there are lower environmental regulations and standards due to opportunities for cost savings. This leads to excessive levels of pollution and environmental degradation. The pollution haven hypothesis has three dimensions. The first is the relocation of heavy polluting industries from developed countries with stringent environmental policies to developing countries where similar policies do not exist, or are not enforced. This may be true especially with the general conclusion that the developed nations contribute the lion share of greenhouse emission that is the major cause of the global warming, and the consequent Kyoto Protocol in which they promised to decrease their emission levels in aggregate of 5\% reduction in the 1990 level of global emissions before the end of a first commitment period in 2012.The second dimension is the dumping of hazardous waste generated from developed countries (industrial and nuclear energy production), in developing countries. This issue was the subject of the Basle Convention on hazardous waste. The last dimension is the unrestrained extraction of non-renewable natural resources in developing countries by multinational corporations engaged in producing petroleum and petroleum products, timber and other forest resources, etc. All the dimensions relate to conscious decisions on environmental policy and how they affect the environment. Existing literatures have also substantiated the claim that lax environmental law or regulation in developing countries attracts FDI (Grossman and Krueger, 1991; Friedman et al, 1992; Smarzynska and Wei, 2001.)

\section{Literature Review}

The relationship between economic growth and foreign direct investment has been intensively analyzed empirically over the past two decades. While some studies observe a positive impact of FDI on economic growth, others detect a negative relationship between the two variables (Aitkin and Harrison (1999), Djankov and Hoekman (2000), Damijan et al. (2001), Konings (2001), Castellani and Zanfei (2002a, 2002b). Mello (1997) lists two main channels through which FDI may be growth enhancing, First, FDI can encourage the adoption of new technology in the production process through capital spillovers. Second, FDI may stimulate knowledge transfers, both in terms of labour training and skill acquisition and by introducing 
alternative management practices and better organizational arrangements. Dees (1998) submits that FDI has been important in explaining China's economic growth, while De Mello (1997) presents a positive correlation for selected Latin American countries. Inflows of foreign capital are assumed to boost investment levels. Blomstrom et al. (1994) report that FDI exerts a positive effect on economic growth, but that there seems to be a threshold level of income above which FDI has positive effect on economic growth and below which it does not. The explanation was that only those countries that have reached a certain income level could absorb new technologies and benefit from technology diffusion, and thus reap the extra advantages that FDI can offer. It is argued that FDI undertaken by multinationals will result in some standardization of technologies across countries (Pearson, 1987; Warhurst and Isnor, 1996; Birdsall and Wheeler, 1993; Levy, 1995).

With respect to FDI and environment, Eskeland and Harrison (1997) argued that foreign firms are significantly more energy efficient and use cleaner types of energy than local firms use. They challenge the pollution haven hypothesis and argued that, liberalization of trade and increased foreign investment in Latin America has not been associated with pollution intensive industrial development and concluded that, protected economies are more likely to favour pollution intensive industries, while openness actually encourages cleaner industries through the importation of developed pollution standards. Lofdalh (2002) argued that the activities of MNCs, collectively, have increased the scale of international trade and production, thereby increasing cross border trade and increased lateral pressure on the environment, defined by expansion, competition, rivalry and conflict amongst them. By reducing transaction costs and responding to market imperfections, the MNCs serve to promote international trade and comparative advantage. Higher domestic cost is an incentive to MNCs to expand production spatially into other countries or in search for additional resources. Copeland, Brian R. and M.S. Taylor (2003) found that, effects of pollution on FDI movement depend not on stringency of policy but also on the type of instrument used. Xing (1998) reported strong evidence on the impact of lax environmental regulation in attracting foreign investment. However, while environmental pollution and movements of capital and "dirty" goods could be observed, lax environmental problem may be difficult to determine. Copeland and Taylor (1994) argued that on the whole, free trade increases world pollution because, increased world income and its skewed distribution, means for a given endowments and trade frictions, a country could import clean goods if its income is sufficiently high.

Some authors found no empirical proof of the pollution haven hypothesis, (Grossman and Krueger, 1993; Eskeland and Harrison, 2003), others showed weak evidence (List and Co, 2000; Smarzynska and Wei, 2004), and a few detected stronger empirical evidence (Keller and Levinson, 2002). In all these works, environmental regulation was considered as exogenous. More recently, some authors consider that the environmental regulation is endogenous. Examining trade, Ederington and Minier (2003) argue that the environmental regulation could be used as a secondary trade barrier to protect domestic industries. Their estimates of a system of two simultaneous equations provide support for modeling pollution abatement costs endogenously while studying their impact on net imports, and show that this impact is stronger than in previous estimates with environmental regulation treated exogenously. (Gallagher, 2002; Schatan, 2002) evaluated the environmental impacts of export-led manufacturing growth in Mexico. Both come to similar conclusions that overall levels of industrial pollution, particularly air pollution, water pollution, and toxics, have increased faster than population growth and faster than the GDP of the economy as a whole in Mexico since the 1980s. They argued that environmental degradation was fueled by the large increases in manufacturing growth and exports that occurred during the period. This is to say that the rate of economic activity in the manufacturing sector corresponded with a growing amount of pollution. Coondo and Dinda (2002) divide countries into groups and continents to test causality between per capita real GDP, used to proxy Growth, and $\mathrm{CO}_{2}$ emission, used to proxy pollution. They found one way causality from pollution to growth for North America, Western Europe, and Eastern Europe, one way causality between Growth to Pollution in Central and South America, Oceania, Japan, and a two-way causality for Asia and Africa.

Oyejide (2005) provided conceptual framework for the analysis of the macroeconomic effects of volatile capital flows. It concluded that capital flows have their pros and cons. This however depends on the initial conditions of the developing economy concerned. It can stimulate growth of the real sectors when the initial conditions are right. It could retard growth however, due to macroeconomic shocks that could undermine the stability of real sector and impose higher adjustment cost on the economy. He therefore recommended 
capacity building as a way of maximizing benefits and minimizing risks from capital flows. Otepola (2002) examines the importance of foreign direct investment in Nigeria. The study empirically examined the impact of FDI on growth. He concluded that FDI contributes significantly to growth especially through exports. Akinlo (2004) investigates the impact of FDI on economic growth in Nigeria using data for the period 1970 to 2001.He found out that both private capital and lagged foreign capital have small and insignificant impact on economic growth. Aliyu (2005) examine the impact of environmental policy on location decision, the outflow of "dirty" Foreign Direct Investment (FDI) on eleven OECD countries and fourteen non-OECD countries. Using disaggregated FDI data, panel data regression, he found out that, "dirty" FDI outflow is positively correlated with environmental policy in eleven OECD countries. However, FDI inflow is not significant in explaining the level of pollution and energy use in fourteen non-OECD countries. There has been little or no country-specific work done to examine relationship between FDI, Growth and Pollution together in Nigeria. The various ones have always concentrated on relationship between FDI and Growth. In this vein, this work is unique.

\section{Methodology}

In this study, annual real GDP is used to proxy growth, annual Co2 is used as proxy for pollution. The data for GDP, Pollution and FDI were obtained from World Bank Development Indicator. The study scope covers the period between 1977 and 2010. The choice of this scope is informed by the availability of uniform data in the country as well desire to study the relationship between the variables over a considerable length of time. The variables are presented in their log forms. Augmented Dickey-Fuller and Philip-Peron test are used to test the stationarity of the variables, and Johansen Co-integration technique is used to establish long run relationship among the variables. Granger causality test is used to test the direction of causality between FDI and economic growth, FDI and Pollution, Economic growth and Pollution, Granger (1969) proposed a time-series data based approach in order to determine causality. In the Granger sense $\mathrm{x}$ is a cause of $\mathrm{y}$ if it is useful in forecasting $\mathrm{y}$. This means that $\mathrm{x}$ is able to increase the accuracy of the prediction of $\mathrm{y}$ with respect to a forecast, considering only past values of $y$. The direction of causality determines the direction of the relationship among variables and Granger causality test has four different directions for these purposes:

a) Unidirectional Granger-causality from $X$ to $Y$ and not Vice-versa

b) Unidirectional Granger-causality from $Y$ to $X$ and not Vice-versa

c) Bidirectional (or feedback) causality from $\mathrm{X}$ to $\mathrm{Y}$, and from $\mathrm{Y}$ to $\mathrm{X}$.

c) Lack of Causality: There is no relationship among the variables,

The model is presented below:

$$
\begin{aligned}
& L G D P_{t}=a_{0}+\sum_{j=1}^{n} a_{1} L G D P_{t-1}+\sum_{j=1}^{n} a_{2} L F D I_{t-1}+u_{1 t} \\
& L G D P_{t}=b_{0}+\sum_{j=1}^{n} b_{1} L G D P_{t-1}+\sum_{j=1}^{n} b_{2} L C o_{t-1}+u_{2 t} \\
& L F D I_{t}=c_{0}+\sum_{j=1}^{n} c_{1} L F D I_{t-1}+\sum_{j=1}^{n} c_{2} L G D P_{t-1}+u_{3 t} \\
& L F D I_{t}=\delta_{0}+\sum_{j=1}^{n} \delta_{1} L F D I_{t-1}+\sum_{j=1}^{n} \delta_{2} L C o 2_{t-1}+u_{4 t} \\
& L C o 2_{t}=\rho_{0}+\sum_{j=1}^{n} \rho_{1} L C o 2_{t-1}+\sum_{j=1}^{n} \rho_{2} L G D P_{t-1}+u_{5 t} \\
& L C o 2_{t}=\sigma_{0}+\sum_{j=1}^{n} \sigma_{1} L C o 2_{t-1}+\sum_{j=1}^{n} \sigma_{2} L F D I_{t-1}+u_{6 t}
\end{aligned}
$$


Diagnostic stationarity tests are carried out to determine the order of stationarity of the variables (the unit root test). The unit root tests are conducted for the variables using the Augmented Dickey-Fuller test and the Phillips-Perron test. Note that the MacKinnon (1996) critical values for the Augmented Dickey-Fuller (ADF) test use the Akaike information criterion (AIC) and Phillips-Perron test using the Newey-West bandwidth and the Bartlett-Kernel spectral estimation method at $1 \%, 5 \%$ and $10 \%$ significance level are -3.626784, 2.945842 and -2.611531 respectively. Stationarity (unit root) tests conducted for the set of variables in our model revealed that all the variables are I(1) variables (integrated of order 1). That is, they are not stationary at levels but are stationary at their various first differences. The second stage involves testing for the existence of a long-run equilibrium relationship among the variables within a multivariate framework. Johansen and Juselius (1990) developed the maximum likelihood estimator for co-integration analysis.

\section{Results}

Stationarity: The first step in this analysis concerns the stationarity of the variables. Granger Causality requires that the series have to be covariance stationary, so an Augmented Dickey-Fuller and Philip-Peron test are used to test the stationarity of the variables. The result is presented in the table 1 in the appendix. For all the series, the null hypothesis, Ho, of non stationarity can be rejected at a 5\% confidence level. Both Philips-Peron Unit Root Test and ADF show that none of the variables was stationary at level. However, all of them are stationary after the first difference; that is, the variables are integrated of order one.

Co-integration: Having satisfied the stationarity condition, the result of the co-integration test is presented in table 2 of the appendix. The result shows that there exist two co- integrating equations at $5 \%$ level of significance and one co-integrating equation at $1 \%$ level of significance. The cointegration test is very significant as it helps to determine whether the variables under study have the tendency to move together (converge) in the long run. This is to say that the existence of cointegration implies that there is a long-run equilibrium relationship existing between the variables in the equation. When the existence of the long run relationship among the variables is established, then further analysis such the Granger causality can be applied. If a set of variables are cointegrated, the effects of a shock to one variable spread to the others, possibly with time lags, so as to preserve a long-run relationship between the variables. The next step is to apply granger causality test to the differenced form of the model, and the result is presented in table 3 in the appendix.

Causality: The result for the causal relationship is shown in table 3 in the appendix. From the result analyzed, it can observed that there that there is no causality found between GDP and FDI. In addition, the result shows that there is no causal relationship found between GDP and Co2. However, causal relationship is shown to run between FDI and Co2. This is obvious, given the significance of the probability value as shown in the granger causality table. This causality runs from FDI to $\mathrm{Co} 2$ but does not run from Co2 to FDI. This shows that the causality is uni-directional (runs one way) as against a bi-directional causality. This suggests that as foreign direct investment grows, the rate of pollution is likely to increase in the economy. This presupposes that the activities foreign direct investors are likely to have a significantly negative impact on the environment in Nigeria. The finding of this study corroborates the fact that large percentage of the type of FDI coming in to the country is in the oil (exploration) sector. The exploration activities have been causing significant environmental pollution in terms of oil spillage. The findings from the study result agree with the result of Ayadi (2009) who found a weak relationship between FDI and economic growth in Nigeria. It also confirms the result by Ogundipe and Aworinde (2011) who did not find any causality.

\section{Conclusion, Recommendations and Policy Implications}

The main purpose of every multinational company is to maximize profit, investment under such a motive will bring certain negative effects to the host countries in addition to a positive impact on economic growth. This paper has thus attempted to investigate the causal relationships between Co2 emission, FDI and economic growth in Nigeria between 1977 and 2010. All the variables were stationary at the first difference of their logarithmic forms. Co-integration analysis showed that the variables have long run relationship. Pairwise Granger Causality tests were used to test direction of causality among the variables. The test shows that there is no causality between growth of GDP and FDI, growth of GDP and Co2. However, there is uni- 
directional causality between growth of FDI and Co2 emission. This means that FDI growth granger- causes growth of $\mathrm{Co} 2$ emission during the period examined. This means that growth rate of pollution in Nigeria is granger caused by growth rate of FDI inflow. This supports the pollution haven hypothesis. The pollution havens hypothesis anticipates the voluntary inflows of foreign companies to countries where there are lower environmental regulations and standards due to opportunities for cost savings. If unchecked, this will lead to excessive levels of pollution and environmental degradation in Nigeria. This paper recommends that there is need for the government of Nigeria to make policy that will ensure that multinational companies use equipment that are environmental friendly. Pollution taxes can also be introduced as a check to the activities of the multinational companies.

The findings have important policy implications. As against the expected view that the direction of causality runs from FDI to economic growth, the case is different in Nigeria. No relationship was established between the two variables within the time examined. This means that inflow of FDI into the country has not affected significantly on the country's growth. This may contradict empirical expectation. This may not be surprising since it has been argued that multinational companies are only interested in aspects of the economy where their interest is mostly served. This is evident given the number of multinational companies in the oil and energy sector, and little or none in other sectors like tourism, agriculture, etc. It also shows that the economy is not attractive to FDI. This result clearly suggests that foreign investors are not likely to invest in Nigeria because of macroeconomic instability as evidence by rising inflation, interest rate and exchange rate volatility, poor infrastructural facilities and high debt burden and incessant social and political instability. The Nigerian economy has not significantly felt the positive impact FDI is suppose to bring to the country. FDI to the country should be diversified in the economy rather than concentrating in the oil sector, which tends to increase environmental pollution. There is need for policy makers to do more in terms of attracting FDI in other sectors of the economy such as the agricultural sector. The focus of this paper so far has been on investigating the causal relationship between foreign direct investment, economic growth and environmental pollution in Nigeria. There are however few other areas of inquiry in the literature for the country. Given the peculiarity of the Nigerian economy in terms of being an oil-dependent economy, a critical examination of the determinants of FDI in Nigeria as well as an impact analysis of FDI in the country are lines of inquiry future researcher should explore.

\section{References}

Adegbite E.O. \& Ayadi, F. S. (2010). The Role of FDI in Economic Development: A Study of Nigeria. World Journal of Entrepreneurship, Management and Sustainable Development, 6(1/2).

Aitken, B. J. \& Harrison, A. (1999). Do Domestic Firms Benefit from Direct Foreign Investment? Evidence from Venezuela. American Economic Review, 89, 605-618.

Akinlo, A. E. (2004). Foreign direct investment and growth in Nigeria: An empirical investigation. Journal of Policy Modeling, 26, 627-39

Aliyu, M. A. (2005).Foreign Direct Investment and the Environment: Haven Hypothesis Revisited. a Paper prepared for the Eight Annual Conference on Global Economic Analysis, Lübeck, Germany, June 9 11, 2005.

Ayadi, F. S. (2009). Foreign Direct Investment and Economic Growth in Nigeria. Proceedings of the 10th Annual Conference of IAABD.

Birdsall, N. \& Wheeler, D. (1993). Trade Policy and Industrial Pollution in Latin America: Where are the Pollution Havens? Journal of Environment and Development, 2(1), 137-149.

Blomström, M. \& Edward, N. W. (1994). Multinational Corporations and Productive Convergence in Mexico". In Baumol, William J., Richard R. Nelsonand Edward N. Wolff (eds.): Convergence of Productivity: Cross National Studies and Historical Evidence. Oxford: Oxford University Press, 263-283.

Castellani, D. \& Antonello, Z. (2002a). Multinational Companies and Productivity Spillovers: Is there a Specification Error? mimeo, University of Urbino (Italy).

Castellani, D. \& Antonello, Z. (2002b). Technology gaps, absorptive capacity and the impact of inward investments on productivity of European firms, mimeo, University of Urbino (Italy).

Coondoo, D. \& Dinda, S. (2002). Causality between Income and Emission: a Country Group-Specific Econometric Analysis. Ecological Economics, 40, 351-367.

Copeland B. R. \& Taylor, M. S. (1994). North-South Trade and the Environment. Quarterly Journal of 
Economics, 109, 755-787.

Copeland, B. R. \& Taylor, M. S. (2003). Trade and the Environment: Theory and Evidence. Princeton: Princeton U. Press

Damijan, J. P., Boris, M., Mark, K. \& Matija, R. (2001). The Role ofFDI, Absorptive Capacity and Trade in Transferring Technology to Transition Countries: Evidence from Firm Panel Data for Eight Transition Countries, mimeo, UN Economic Commission for Europe, Geneva.

Dees, S. (1998). Foreign direct investment in China: Determinants and effects. Economics of Planning, 31, 17594.

De Mello, L. R. (1997). Foreign Direct Investment in developing countries and growth: A selective survey. Journal of Development Studies, 34(1), 1-34.

Djankov, S. \& Bernard, H. (2000). Foreign Investment and Productivity Growth in Czech Enterprises. World Bank Economic Review, 14(1), 49-64.

Eskeland, G. S. \& Harrison, A. E. (1997). Moving to Greener Pastures? Multinationals and the Pollution-haven Hypothesis. World Bank Working Paper Series N0.1744.

Ederington, J. \& Minier, J. (2003). Is environmental policy a secondary trade barrier? An empirical analysis. Canadian Journal of Economics, 36(1), 137-154

Friedman, J. D. Gerlowski, K. \& Silberman, J. (1992). What Attracts Foreign Multinational Corporations? Evidence from Branch Plant Location in the United States. Journal of Regional Science, 32, 403-418.

Gallagher, K. (2002). Industrial Pollution in Mexico: Did NAFTA Matter?" in Carolyn L. Deere and Daniel C. Esty, eds., Greening the Americas: NAFTA's Lessons for Hemispheric Trade, Cambridge: MIT Press.

Granger, C. W. J. (1969). Investigating causal relation by econometric and cross-sectional method. Econometrica, 37, 424-438.

Grossman, G. \& Krueger, A. (1993). Environmental Impact of North American Free Trade Agreement. In P. Garber: The Mexico US Free Trade Agreement, MIT Press, Cambridge Massachussetts.

Jenkins, C. \& Thomas, L. (2002). Foreign direct investment in Southern Africa: determinants, characteristics and implications for economic growth and poverty alleviation, University of Oxford [internet.] Available from http://www.csae.ox.ac.uk/reports/pdfs/rep2002-02.pdf

Johansen, S. \& Juselius, K. (1990). Maximum Likelihood Estimation and Inference on Cointegration - with Applications to the Demand for Money. Oxford Bulletin of Economics and Statistics, 52, 169-210

Keller, W. \& Levinson, A. (2002). Pollution abatement costs and foreign direct investment ináows to U.S. States. Review of Economics and Statistics, 84(4), 691ñ703.

Konings, J. (2001). The Effects of Foreign Direct Investment on Domestic Firms: Evidence from Firm Level Panel Data in Emerging Economies. Economics of Transition, 9, 619-633.

Levinson, A. (2003). Environmental regulatory competition: a status report and some new evidence. National Tax Journal, 56, 91-106.

Levy, D. L. (1995). The Environmental Practices and Performance of Transnational Corporations. Transnational Corporations, 4(1).

Lofdalh, C. L. (2002). Environmental Impacts of Globalisation and Trade: A systems study, The MIT Press, Cambridge, Massachusetts.

MacKinnon, J. G. (1996). Numerical distribution functions for unit root and cointegration tests. Journal of Applied Econometrics, 11, 601-618.

Noorzoy, M. S. (1979). Flows of Direct Investment and their Effects on Investment in Canada. Economic Letters, 2(3), 357-61.

Ogundipe, M. S. \& Aworinfe, O. B. (2011). An analysis of causality between Economic and Foreign Direct Investment in pre- and post-deregulated Nigerian economy (1970-2007). European Journal of Scientific Research, 53(3), 317-325

Otepola, A. (2002). Foreign Direct Investment as a factor of Economic Growth in Nigeria. Institute for Economic Development and Planning (IDEP), Dakar, Senegal.

Oyejide T. A. (2005). Capital Flows and Economic Transformation. A Conceptual Framework on Proceedings of Central Bank of Nigeria 5th Annual Monetary Policy Conference with the theme "Capital Flows and Economic Transformation in Nigeria. Held at the CBN Conference Hall, Abuja. November 10th to 11 th.

Pearson, C. S. (1987). Multinational Corporations, Environment, and the Third World. Durham, NC: Duke University Press, 3-31.

Schatan, C. (2002). Mexico's Manufacturing Exports and the Environment Under NAFTA. The Environmental 
effects of Free Trade. Montreal, North American Commission for Environmental Cooperation.

Smarzynska, B. \& Wei, S. (2001). Pollution Havens and the Location of Foreign Direct investment: Dirty Secret or Popular Myth? June 10, 2001. Washington, D.C.: International Trade Team - Development Economics Research Group, The World Bank. Mimeo

Smarzynska, B. \& Wei, S. J. (2004). Pollution havens and foreign direct investment: Dirty secret or popular myth? Contributions to Economic Analysis and Policy, 3 (2), 1 ñ32

Warhurst, A. \& Isnor, R. (1996). Environmental Issues for Developing Countries Arising from Liberalised Trade in the Mining Industries. Natural Resources Forum, 20(1), 27-35.

Xing, Y. \& Kolstad, C. D. (1996). Do Lax Environmental Regulations Attract Foreign Investment? Paper presented to National Bureau of Economic Research Workshop on Public Policy and the Environment, Cambridge, MA.

\section{APPENDIX}

Table 1: UNIT ROOT RESULT

\begin{tabular}{lllllll}
\hline VARIABLE & $\begin{array}{l}\text { AUGMENTED } \\
\text { FULLER }\end{array}$ & DICKEY & $\begin{array}{l}\text { ORDER OF } \\
\text { INTEGRA- } \\
\text { TION }\end{array}$ & PHILLIPS-PERRON & $\begin{array}{l}\text { ORDER OF } \\
\text { INTEGRA- } \\
\text { TION }\end{array}$ \\
\hline LCovel & 1 $^{\text {ST }}$ Diff & & Level & 1 $^{\text {st } \text { Diff }}$ & \\
LGDP & -1.72536 & $-6.610671^{*}$ & I(1) & -1.725366 & $-6.566730^{*}$ & I(1) \\
LFDI & 1.75608 & $-4.476408^{*}$ & I(1) & 1.478406 & $-4.550981^{*}$ & I(1) \\
& 0.21549 & $-10.67431^{*}$ & I(1) & -0.833745 & $-10.63315^{*}$ & I(1)
\end{tabular}

Note: ${ }^{*}, *$ and ${ }^{* * *}$ indicate the rejection of the null hypothesis at $1 \%, 5 \%$ and $10 \%$ level of Significance, respectively. The lag lengths are selected using AIC.

Table 2: Result of the Co-integration Test

\begin{tabular}{lllll}
\hline $\begin{array}{l}\text { Hypothesized No } \\
\text { of CE\{s\} }\end{array}$ & Eigenvalue & Trace Statistic & $\mathbf{0 . 0 5}$ critical value & Prob ${ }^{* *}$ \\
\hline $\mathrm{r}=0^{*}$ & 0.739519 & 56.91817 & 35.19275 & 0.0001 \\
$\mathrm{r} \leq 1^{*}$ & 0.477429 & 24.63272 & 20.26184 & 0.0117 \\
$\mathrm{r} \leq 2$ & 0.314337 & 9.056848 & 9.164546 & 0.0524 \\
\hline
\end{tabular}

Note * denotes rejection of the hypothesis at the 0.05 level

TABLE 3: SUMMARY OF GRANGER CAUSALITY TEST RESULT

\begin{tabular}{llll}
\hline Dependent variable & $\mathbf{\Delta L F D I}$ & $\mathbf{\Delta L G D P}$ & $\mathbf{\Delta} \mathbf{L C O}_{2}$ \\
\hline$\Delta \mathrm{LFDI}$ & - & $0.69196(0.5128)$ & $1.02412(0.3781)$ \\
$\Delta \mathrm{LGDP}$ & $0.67995(0.5185)$ & - & $0.83588(0.4462)$ \\
$\Delta \mathrm{LCO}_{2}$ & $4.11759(0.0327)^{* *}$ & $0.17988(0.8365)$ & - \\
\hline
\end{tabular}

Note: ${ }^{*}, * *$ and ${ }^{* * *}$ indicate the rejection of the null hypothesis at $1 \%, 5 \%$ and $10 \%$ level of significance, respectively. 